\title{
A new look at the development agenda
}

\section{José Antonio Ocampo \\ Executive Secretary of the \\ Economic Commission for \\ Latin America and \\ the Caribbean \\ (ECLAC) \\ jaocampo@eclac.cl}

This essay summarizes some of the main ideas behind proposals for a new development agenda. It highlights first the need to strike a new balance between the market and the public interest, and to understand by "public policies" any initiative organized in pursuit of common goals, and not just State actions. The author makes five proposals for a new agenda: i) more balanced globalization with genuine respect for diversity, underpinned by a network of regional institutions; ii) a broad view of macroeconomic stability and the role of countercyclical policies; iii) the use of development strategies to foster innovation and production complementarities, without which macroeconomic policies are insufficient to generate dynamic growth; iv) improved social linkages, through long-term equity and inclusion policies, complemented by economic growth to create sufficient high-quality employment and measures to reduce structural heterogeneity among production sectors; v) subordination of the economic system to broader social objectives. 


\section{Introduction}

Liberalization was presented to the developing world as providing a way out of inefficient strategies associated with trade protection and high levels of State intervention, as well as the rent-seeking behaviour that those strategies encouraged. It was also seen as a means of fully exploiting the opportunities generated by globalization. This view represented a significant break with the idea, which underlay development strategies for several decades, that "late industrialization" required a significant degree of State intervention in order to succeed. The Washington Consensus provided one of the best summations of this reform agenda, although it certainly did not reflect its most radical version, which called for a minimalist State (Williamson, 1997). It was also, it should be added, a manifestation of the optimism that the reform agenda generated a decade ago.

During the last few years, the wisdom behind this vision has been called into question. The Asian crisis was what probably dealt it the hardest blow. That crisis made patently clear that, without an adequate institutional setting, financial liberalization could be the source of severe macroeconomic instability. The strong views expressed by "global civil society" since Seattle indicate that globalization itself is now being questioned and reflect a basic substratum of discontent in the industrialized world. In developing countries, disenchantment with reforms is also growing, but its political manifestations are more disorganized and its agenda unclear.

More broadly, dissatisfaction with the results of reforms is on the rise. Trade and foreign direct investment have boomed, but the "promised land" of high growth rates is increasingly regarded as a mirage. In Latin America -the region where reforms have gone the furthest- growth in the 1990 s was only $3.2 \%$ a year, far below the $5.5 \%$ record set during the three decades of State-led development from the 1950s to the 1970s. Sub-Saharan Africa's performance, and that of the least developed countries in general, continues to be highly

$\square$ A prior version of this paper was presented at the American Economic Association Annual Meeting Panel "Toward a PostWashington Consensus on Development and Security", New Orleans, 5-7 January 2001. insufficient. Many transition economies still have levels of economic activity below those seen prior to the "big bang". Although most of the Asian economies that underwent the crisis did recover, they are still struggling with its financial repercussions. Notable exceptions are obviously China and India, which are certainly not on the list of the most highly reformed economies. Even in the industrialized world, growth in the 1990s was still far from what it was in the "golden age" of 19501973; the United States did reach those rates, but only during the second half of the decade.

Distributive tensions are running high and are probably intensifying. Income disparities between developed and least developed countries continue to increase (UNDP, 1999). Income distribution has worsened in a broad group of both developed and developing countries. According to one account, the countries where income distribution has worsened contain 57\% of the world's population and those where it has improved $16 \%$, with the remainder experiencing no clear trend (Cornia, 1999). The growing skills-based income differential is a worldwide phenomenon. Debate continues as to whether it is the result of trade liberalization, technological trends or a weakening of social safety nets. The asymmetry existing between factors that cross international borders (capital, highly skilled labour) and those that cannot (low-skilled labour), together with the increasing difficulties governments are having in providing social safety nets, are certainly part of the explanation (Rodrik, 1997).

Recent events and the discontent they have generated have, in turn, spurred a constructive debate that promises to enrich the development agenda. The last few years have indeed made the debate somewhat more pluralistic. Alternative views of development have made some headway. New areas of emphasis -institution-building, social safety nets and the "ownership" of development policies, to name a fewhave been brought into the international policy debate. Is this an indication that the development agenda is in fact changing? Perhaps, but this is still unclear. Indeed, new concepts and areas of emphasis are often mere "add-ons" to what is, by and large, the same policy agenda, with new generations of reforms simply being appended to what are regarded essentially as the correct 
foundations. Seen in a less favourable light, they are merely new garments draped over the same ideas. Markets, particularly financial markets, have not really internalized the need for a new development agenda, and financial agents continue to call for more liberalization at the national and world levels, i.e., plainly for more of the "first generation" of reforms. This remains the dominant force in a world of weakened national polities and an even weaker transition to a global polity.

This paper summarizes some of the basic concepts underlying the call for a new development agenda. ${ }^{1}$ Two intersecting themes in the literature on this subject should be emphasized at the outset. The first is the call for a new balance between the market and the public interest. This should not be viewed as running counter to the operation of the market, since actions that ensure an adequate supply of public goods, help to complete markets, assist non-competitive markets to function properly, exploit positive and avoid negative externalities, or ensure an equitable distribution of the benefits of development, can serve as powerful mechanisms for enhancing market development through a variety of economic, social and political channels. An assertive public policy approach of this sort will be, if correctly applied, more market-friendly than the alternative approaches that tended to predominate during the first wave of reforms.

The second theme is that, rather than being restricted to State actions, the concept of public policy should be understood as any organized form of action that pursues objectives of collective interest. This definition of public policy is in keeping with an awareness of the need to open up opportunities for participation by civil society and to work to overcome a crisis of the State that affects the developing world and, indeed, the world at large. It thus aims at correcting both "market failures" and "government failures" and, more generally, at building and rebuilding institutions (or, in the terminology of the new institutional literature, institutions and organizations). This is unquestionably one of the most complex tasks awaiting the developing and transition economies. Moreover, it is the most pressing task -yet at the same time one that has so far received insufficient attention- in the process of building a better international order.

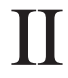

\section{A more balanced form of globalization based on a genuine respect for diversity}

The need to "civilize" the global economy (Helleiner, 2000) or, in the words of the United Nations Millennium Declaration, "to ensure that globalization becomes a positive force for all the world's people" (United Nations, 2000) is the most crucial issue. Although powerful technological and economic processes underlie it, there is no doubt that the globalization process can be shaped, and indeed the form that it has been assuming has largely been shaped by explicit policy decisions.

The most troublesome aspect of this situation is the incomplete and even lopsided character of the current globalization process and the international policy agenda that accompanies it, which is reproducing

\footnotetext{
${ }^{1}$ References have been kept to a minimum, although the literature on the topic is extensive.
}

long-standing asymmetries in the world economy and creating new ones. Four issues figure prominently in the current agenda: free trade, intellectual property rights, investment protection, and financial and capitalaccount liberalization. The latter has been the object of various qualifications during recent crises, including the proviso that it should be well sequenced and that emphasis should be given to longer-term flows and to institutional development. Moreover, in the area of trade, liberalization is, in turn, incomplete and asymmetric, as "sensitive" items of great interest to the developing countries are subject to the highest levels of protection in the industrialized world.

Meanwhile, other issues are conspicuously absent from the current agenda: labour mobility; international rules on taxation, particularly of capital (essential to guarantee adequate taxation of this highly mobile factor); the design of truly international competition 
rules and codes of conduct for multinational firms; and compensatory financing to ensure the inclusion of those countries and social groups that tend to be left behind in the globalization process.

This is, in turn, a reflection of the most serious asymmetry of all: the imbalance between the rapid globalization of (some) markets and the conspicuous absence of a truly international social agenda. The latter is, in fact, largely confined to the definition of common international principles (through United Nations summits) and the as yet incipient emergence of international legislation. The decline of official development assistance (ODA) is one of the most compelling pieces of evidence of the lack of commitment to a truly international social agenda, as is the growing conditionality that is attached to international financial support in general.

More broadly, it is increasingly being recognized that globalization has underscored the need to provide a number of global public (political, social, economic and environmental) goods, as many previously national (and, further back in history, local) public goods are increasingly becoming global in nature (Kaul, Grunberg and Stern, comps., 1999). There is, however, a striking contrast between the recognition of this fact, on the one hand, and, on the other, the weakness of international arrangements to provide such public goods and the low level of funding allocated for this purpose.

These asymmetries obviously reflect basic political features and aspects of the world's political economy. The lopsided character of the current globalization process and agenda undoubtedly reflects the predominance of major countries and large multinationals. However, it also reflects the disorganization of many actors, particularly developing countries, in the international policy debate. This state of affairs is associated not only with a weakening of the historical mechanisms for concerted action by developing countries (e.g., the Group of 77), but also with the "policy competition" that globalization itself has generated (i.e., the strong incentive that each country has -in this era of mobile capital and increasingly footloose production- to claim that it is a more attractive investment site than other nations). Thus, the asymmetries characterizing world power relations and the high cost of generating international coalitions to compensate for those asymmetries have become even more important today.

A complicating feature of the political situation and of the political economy is obviously the reluctance of most countries to give up economic sovereignty to international organizations. Under the influence of the strong market forces characteristic of globalization, which tend to weaken nation States, and the unilateral national liberalization processes that have been taking place simultaneously, government regulations have weakened worldwide. Many analysts perceive this result as an advance, but it is also a source of significant distortions and risks, particularly -but not only-in the area of finance. It should be added that, although open regionalism is also a feature of globalization, and strong integration forces have been at work in many parts of the developing world (e.g., Latin America and SouthEast Asia), this has not led to strong developing-country coalitions. Indeed, the European Union aside (and even in this case only in a limited sense), countries are also unwilling to give up their sovereignty to regional organizations.

These political and political economy features have major implications for international reform. The most obvious are that the pressure for substantive reform will be weak, and thus that a more balanced globalization agenda and stronger global governance may not materialize, that any balanced negotiation process would be cumbersome, and that negotiation processes may underestimate or bypass the interests of certain actors altogether. The lack of truly international institutions also means that institutions that have developed in the past at the national level will not be available at the global level or will only have limited functions.

Because of the incompleteness of the relevant international arrangements, weaker actors should continue to demand national autonomy in crucial areas, particularly in terms of the choice of economic and social development strategies. Moreover, national autonomy is the only system that is consistent with the promotion of democracy at the world level. There is indeed no sense in promoting democracy if representative and participatory processes at the national level are given no role in shaping economic and social development strategies. This is also consistent with the view that institution-building, social cohesion and the accumulation of human capital and technological capabilities (knowledge capital) are essentially endogenous processes. To borrow a term from Latin American structuralism, development can only come "from within" (Sunkel, 1993). Support for these endogenous processes, respect for diversity and the design of rules that allow it to flourish are essential elements of a democratic, development-oriented world order. 
A final, crucial implication is that no international architecture is neutral in terms of the equilibrium of international relations. In this sense, an international system that relies on a very small number of world institutions will be less balanced than one that relies on a network of regional institutions, and countries with very limited power in the international arena will be better off if they are active participants in regional schemes. These regional schemes can indeed provide degrees of freedom and mutual support that would not be available at the national level. The international order should thus provide ample scope for strong regional institutions while at the same time upholding a rulesbased global order (i.e., a system of "open regionalism", to borrow a term from the literature on economic integration). Indeed, operating through regional institutions may be the best way to gradually build up a better international order.

\section{III}

\section{A broad view of macroeconomic stability and the role of countercyclical policies}

The concept of macroeconomic stability has undergone considerable changes in the economic discourse over the past two decades. During the post-war years dominated by Keynesian thinking, this concept was basically defined in terms of full employment and stable economic growth, accompanied by low inflation and sustainable external accounts. Over time, however, fiscal balance and price stability moved to centre stage, while the Keynesian emphasis on real economic activity took a back seat and eventually began to fade away altogether.

The consistency that ought to characterize macroeconomic policies should be oriented by a broad definition of stability that recognizes that there is no single correlation between its alternative definitions and that significant trade-offs may be involved. Two lessons are particularly important in this regard. The first is that real instability is very costly. A narrow view of inflation targeting may thus be as damaging as past macroeconomic practices that underestimated the costs of inflation. Recessions entail a significant loss of resources that may have long-run effects: firms may sustain irreparable losses in terms of both tangible and intangible assets (tacit technological and organizational knowledge, commercial contacts, the social capital accumulated in the firm, its goodwill, etc.); the human capital of the unemployed or the underemployed may be permanently lost; and children may leave school and never return. Volatile growth leads to a high average rate of underutilization of production capacity, reducing productivity and profits and thus adversely affecting investment (Ffrench-Davis, 1999). The uncertainty associated with variability in growth rates may consequently have stronger effects on capital accumulation than moderate inflation. Indeed, it encourages "defensive" microeconomic strategies (i.e., those aimed at protecting the existing corporate assets of firms that find themselves in an unfriendly environment) rather than the "offensive" strategies that lead to high investment rates and rapid technical change.

The second lesson is that private-sector deficits are just as costly as public-sector ones. Moreover, risky private-sector balance sheets may be as damaging as flow imbalances. In financially liberalized economies, both may interact in non-linear ways with capitalaccount shocks. The lack of rigorous domestic financial regulation and supervision typical of the early phases of financial liberalization is part of this, but is certainly not the whole story. Boom-bust cycles are an inherent aspect of financial markets. Private spending booms and risky balance sheets tend to accumulate during periods of financial euphoria and are the basis for crises once exceptional conditions normalize. During such bouts of euphoria, economic agents tend to underestimate the intertemporal inconsistency that may be involved in existing spending and financial strategies. When crises lead to a financial meltdown, the associated costs are extremely high. Asset losses may wipe out years of capital accumulation. The socialization of losses may be the only way to avoid a systemic crisis, but this will affect future fiscal (or quasi- 
fiscal) performance. Restoring confidence in the financial system takes time, and the financial sector itself becomes risk-averse, which undermines its ability to perform its primary economic functions.

These two lessons are basically interconnected, as financial boom-bust cycles have been the predominant source of business cycles in the developing world. The essential task of macroeconomic policy is thus to manage them with appropriate countercyclical tools. The experience of developing countries indicates that managing volatility requires a combination of three policy packages, whose relative importance will vary depending on the structural characteristics and the macroeconomic policy tradition of each country (Ocampo, 2000). The first is consistent and flexible macroeconomic -fiscal, monetary and exchange-ratepolicies aimed at preventing public or private agents from accumulating excessive levels of debt and at forestalling imbalances in key macroeconomic prices (exchange and interest rates) and in the prices of fixed and financial assets. The second is a system of strict prudential regulation and supervision with a clear countercyclical orientation. This means that prudential regulation and supervision should be tightened during periods of financial euphoria to counter the mounting risks incurred by financial intermediaries. The third element is a liability policy aimed at ensuring that appropriate maturity profiles are maintained with respect to domestic and external public and private commitments. Prudential capital-account regulations (i.e., those applied during periods of euphoria to prevent excessive borrowing) can play an essential role both as a liability policy -encouraging longer-term flows- and as an instrument that provides additional degrees of freedom for the adoption of countercyclical monetary policies.

Managing countercyclical macroeconomic policies is no easy task, as financial markets generate strong incentives for developing countries to overspend during periods of financial euphoria and to overadjust during crises. Moreover, globalization places objective limits on national autonomy and exacts a high cost for any loss of credibility when national policy instruments are poorly administered. For this reason, it may be necessary for macroeconomic policy management to be supported by institutions and policy instruments that help to provide credibility, including fiscal stabilization funds and independent central banks. On the other hand, the explicit renunciation of policy autonomy (e.g., by adopting hard pegs or a foreign currency) is hardly a solution to this dilemma. Instead, this simply predetermines the nature of the adjustment, and may make business cycles more intense. If this occurs, the market may not validate (through reduced country risk) the hypothetical increase in "credibility" generated by the decision to relinquish policy autonomy.

The basic solution to the dilemma created by the lack of adequate degrees of freedom to undertake a countercyclical macroeconomic policy lies in the international arena (Eatwell and Taylor, 2000; Ocampo, 2001). This means that a first, essential role of international financial institutions, from the point of view of developing countries, is to counteract the procyclical effects of financial markets. This can be achieved by smoothing out boom-bust cycles at source through adequate regulation and by providing developing countries with additional degrees of freedom to adopt countercyclical policies (e.g., adequate surveillance and incentives to prevent the build-up of risky macroeconomic and financial conditions during periods of financial euphoria, together with mechanisms to smooth out adjustments in the event of abrupt interruptions of private capital flows). A second, equally essential role is to counter the concentration of lending by providing access to those countries and agents that tend to be subjected to rationing in private international capital markets. 


\section{IV}

\section{Macroeconomic policies are not enough: the role of productive development strategies}

The idea that the combination of open economies and stable macroeconomics -in the limited sense in which this term has come to be used, i.e., fiscal balances and low inflation- would by itself spur rapid economic growth has thus far not been borne out. This has sparked an unresolved debate concerning the underlying reasons for this result. The orthodox interpretation is that markets have not been sufficiently liberalized. This interpretation runs up against the fact, however, that the periods of fastest growth in the developing world during the post-war era, as well as the longest-lasting episodes of rapid growth (e.g., the East Asian or, most recently, the Chinese and Indian "miracles" or, in the past, the periods of rapid growth in Brazil or Mexico), have not coincided with phases of extensive liberalization, even in cases where they have involved the use of the opportunities provided by international markets on a large scale (which is a more common though not universal feature).

Two alternative interpretations emphasize other determinants of aggregate economic growth or market failures. In the first case, inadequate institutional development or human capital are seen as the explanation for slow growth. These factors are certainly crucial but, here again, this interpretation needs to explain why faster growth was possible in periods during which these factors were in even shorter supply. The second variant emphasizes the fact that, in order to be efficient, liberalized markets require full-fledged "mesoeconomic" policies: active competition policies, public regulation of non-competitive markets or markets with strong externalities, and the correction of market failures in factor markets, particularly the markets for long-term capital, technology, labour training and land. Policies to correct market failures are indeed essential to ensure more efficient markets, and they may also have effects on equity, but the relationship between these market failures and growth is less clear. Failures in long-term capital and technology markets are probably the most important in this regard.

A more promising line of inquiry draws upon the different historical variants of structuralism in economic thinking, broadly defined. This view emphasizes the close connection among structural dynamics, investment and economic growth. According to this view, economic growth is not a linear process, in which "representative firms" grow or new representative firms are added and then produce a given set of goods on an extended scale. It is rather a more dynamic process in which some sectors and firms grow and move ahead while others fall behind, thereby completely transforming economic structures. This process involves a repetitive phenomenon of "creative destruction", to use Schumpeter's metaphor (1962, chap. VIII). Not all sectors have the same ability to inject dynamism into the economy, to "propagate technical progress", according to the classical concept advanced by Prebisch (ECLAC, 1951). The complementarities (externalities) among enterprises and production sectors, along with their macroeconomic and distributive effects, can produce sudden jumps in the growth process or can block it (Rosenstein-Rodan, 1943; Taylor, 1991 and Ros, 2000) and, in so doing, generate successive phases of disequilibria, according to Hirschman's (1961) classical view. Since technical know-how and knowledge in general are not available in fully specified blueprints, the growth path of firms entails an intensive process of adaptation and learning, closely linked to production experience, that largely determines the accumulation of technical, commercial and organizational know-how (Katz, 1976 and Amsden, 2001).

The common theme in all these theories is the idea that economic growth is intrinsically tied to the structural context, which is made up of productive and technological apparatuses, the configuration of factor and product markets, the characteristics of entrepreneurial agents, and the way in which these markets and agents relate to the external environment. The leadership exercised by certain sectors and firms is, in this case, the essential dynamic factor that drives economic growth. In the developing world, many of the dynamic forces are associated with the successful adaptation of activities previously developed in the industrialized world, through import substitution, export promotion or a combination of both. 
Although alternative formulations can be used, one approach that is particularly promising in terms of its policy orientation emphasizes two essential concepts: innovation and complementarities (linkages). In this formulation, innovation is viewed as any economic activity that introduces a new way of doing things. The best definition was provided by Schumpeter (1961, chap. II) almost a century ago: new goods and services, or new qualities of goods and services; new production methods or marketing strategies; the opening of new markets; new sources of raw materials; and new market structures. The second concept emphasizes the role of strategic synergies that -through the externalities that the various economic agents generate among themselves (Hirschman, 1961)- determine the "systemic competitiveness" of the relevant production structures (ECLAC, 1990). The existence of dynamic scale economies is the essential feature of both innovations and their diffusion, as well as of the development of complementarities. Institutional development may be viewed as an innovation, but it is also an essential ingredient in such complementarities.

These ideas have recently been used by several authors to emphasize the need for a productive development strategy as a basic component of a dynamic, open developing economy, a long-standing theme in "late industrialization" (or, more precisely, late development) literature. Thus, Rodrik (1999) has made a strong argument for a "domestic investment strategy" to kick-start growth, and ECLAC (2000) has referred to the need for a strategy of structural transformation. The essential role of strong State/ business-sector partnerships is set forth by Amsden (2001), as is the need for "reciprocal control mechanisms" that tie incentives to results in order to ensure that the former do not merely lead to rent-seeking behaviour.

This interpretation brings out a central feature of successful development experiences in the past: a strong industrialization drive built on solid State/ business-sector partnerships. Will opening markets with neutral incentives, arms-length governmentbusiness relations and multilateral (Uruguay Round) constraints on traditional development instruments produce the same result? Or, to be more precise, will opening markets provide a substitute for active productive development policies? It remains to be seen, but the results so far are not encouraging, although they may be skewed by certain features of the transition period. The "destructive" elements generated by the adverse structural shift in the growth/ trade deficit trade-off and the break-up of domestic linkages and national innovation systems have been stronger than the "creative" opportunities generated by the (still insufficient) market access and innovations introduced by the spread of multinational firms (Ocampo and Taylor, 1998; UNCTAD, 1999, chap. IV and ECLAC, 2000). In any case, if the past is a correct guide and structural interpretations are valid, then the use of explicit productive development strategies aimed at encouraging innovation (in the broad sense of the term) and helping to build up complementarities would appear to be a better route to take, even in the open developing economies of today. The international community should regard such strategies as an essential ingredient of successful development and should continue to search for instruments for implementing such strategies that do not degenerate into "beggar-thy-neighbour" competition for footloose production activities.

In the developing countries, a significant institutional and organizational effort is required to devise appropriate instruments for active production policies, as the old apparatuses of intervention were either dismantled or significantly weakened during the liberalization phase in many (if not most) of these countries. An effort must also be made to design instruments that, aside from being consistent with the open economies of today, avoid the "government failures" that characterized some of the tools used in the past (rent-seeking and cronyism).

The effective incorporation of the sustainable development agenda is an additional demand being placed on production strategies today. Indeed, the degree of environmental degradation generated by developing countries at intermediate or even low stages of development indicates that sustainability is hardly a luxury that can be postponed. This objective involves much more than conserving the natural resource base. In essence, it calls for the mobilization of investment in dynamic production sectors which use clean production methods and technologies and in which competitiveness is achieved through the accumulation of capital in the broad sense of the term (i.e., human, social, physical and natural capital). A shift in the developing countries from a reactive to a more proactive policy in this area is thus crucial, as is its necessary counterpart: the effective flow of resources from the industrialized nations to finance the global environmental agenda based on the principle of shared but differentiated responsibilities. 


\section{V}

\section{Improved social linkages}

In economic terms, social progress may be thought of as the result of three basic factors: a long-term social policy aimed at improving equity and guaranteeing inclusion; economic growth that generates high-quality employment in adequate quantities; and the reduction of the structural heterogeneity of production sectors in order to narrow the productivity gaps between different economic activities and different economic agents. As the following section indicates, economic considerations are obviously not the only criteria to be used in designing social policy.

The World Bank (2001) has formulated three basic objectives for a poverty-reduction strategy: opportunity, security and empowerment. In a revised formulation, we could argue that equity and inclusion should be equated with broad access to resources, basic protections, voice and participation. Equitable access to resources is the key to equal opportunity, not only in the economic sense, but also in its social, cultural and political dimensions. In the specific case of investment in human capital, this brings out the essential character of social spending as a productive investment. Basic protections are necessary to free people from "negative risks" (sickness, unemployment and, worst of all, hunger) in order to allow and encourage them to take "positive risks", particularly those associated with innovation. Protection from "negative risks" is intrinsic in high-quality employment. Ensuring that people have a voice is essential to guarantee that the interests of the poor are adequately taken into account in decisions that affect them. Through participation, poor people become central actors in building their own future. In many instances, organized communities have been a basic instrument of social and economic change and thus a central element of institution-building.

To achieve these objectives, social policy should be guided by three basic principles: universality, solidarity and efficiency (ECLAC, 2000, chap. 3). This subject has been surrounded by a great deal of confusion in recent years, as instruments -targeting, criteria of equivalency between contributions and benefits, decentralization, private-sector participation- rather than principles have been guiding social-sector reforms. Moreover, these guiding principles emphasize the fact that social policy is a basic instrument of social cohesion (integration), and policy tools should therefore be clearly subordinated to the broader principles. Thus, targeting should be seen as an instrument for attaining universal coverage of basic services, and certainly not as a substitute for universality. Equivalency criteria should be applied in a way that is not inconsistent with solidarity. Properly managed, such criteria, along with decentralization and private-sector participation, are instruments for achieving efficiency.

To enhance equity, social policy should act upon the structural determinants of income distribution: education, employment, wealth distribution and demographic dependence, as well as their gender and ethnic dimensions. These factors are the key elements in the inter-generational transmission of inequality and poverty. Breaking these intergenerational links is therefore vital for a successful social strategy. This should be reflected, in particular, in integrated policies to assist the poor.

Education is a highly important element in equitable growth, particularly in the knowledge/ information age. But its objectives clearly go beyond these "human capital" dimensions: it is also a key factor in democratic development and strong citizenship, and more broadly, in self-realization. Its effects on equity may have been over-emphasized in recent discussions, however, since in a highly segmented society, education is also an instrument of segmentation. This factor has to be taken into serious consideration if education is to be used to improve equity. Moreover, inadequate highquality job creation will defeat efforts made in the area of education, in terms of both the accumulation of human capital (at the extreme, it migrates; under more usual circumstances, it remains underemployed) and equity (occupational segmentation then multiplies the effects of educational segmentation). The link between economic growth and social progress is thus particularly crucial in this regard. In fact, this, in conjunction with the other linkages that are mentioned below, clearly emphasizes the fact that social policy alone is not enough: it must be supported by a sound macroeconomy and active production strategies if it is to bear fruit.

In the rapidly changing environment that characterizes modern economies, the adaptability of labour to technical change and the business cycle is 
increasingly important. The crucial contributing factors in this regard are strong labour training schemes; institutions that enhance cooperation, both at the national level (social dialogue) and within firms; adequate social protection, both of an ongoing nature and of the type needed to cope with adverse events; and a prudent minimum wage policy. While flexibility may be an ingredient, provided it is accompanied by greater protection, it is only one of a number of alternative instruments. In this regard, it should be remembered that more flexible labour markets may adversely impact other factors that have positive effects on adaptability, particularly labour-business cooperation. Most importantly, flexibility should not be seen as a substitute for adequate macroeconomic policies. Indeed, in an unstable macroeconomic environment, or in the presence of slow economic growth, job creation will be weak in any case, and additional flexibility may lead to a rapid deterioration in the quality of employment. Flexibility has, in other words, negative externalities (it may undermine jobs that would otherwise be stable) that should not be ignored.

Poor economic growth affects equity in another way that plays a crucial role in developing countries: it increases structural heterogeneity. This term, drawn from the Latin American structuralist school, is preferred to "dualism" because the heterogeneity that characterizes developing countries and societies cannot be described in terms of a duality between a "modern" and a "traditional" sector and because low-productivity sectors are continually being created and transformed; only some of the sectors that are on the decline can be called traditional. In the absence of strong job creation in dynamic activities, low-productivity activities mushroom. This is what happened in Latin America in the 1990s: the region generated more "world class" firms (many of them subsidiaries of multinationals) that were able to integrate successfully into the global economy, but its low-productivity activities also increased; in fact, they absorbed 7 out of every 10 new workers during the years of growth preceding the Asian crisis (ECLAC, 2000, chap. 1). There is, in fact, no automatic mechanism that guarantees that rapid technological innovation in dynamic activities will fuel swift economic growth: in the absence of adequate domestic linkages -or if the "destructive" effects of productive restructuring, and the defensive microeconomic strategies that accompany them, predominate- it may simply increase structural heterogeneity. If this happens, the growth effects will be weak and additional tensions will be created in relation to equity.

The links between the modernization of leading economic sectors and the rest of the economy are thus crucial, not only for growth but also for equity. Productive development strategies can play a vital role in both dimensions. This also underscores the importance of a good distribution of production assets. Indeed there is strong evidence that an appropriate distribution of production assets which generates a universe of strong small firms is associated with a better distribution of income (and less concentration of power in general). Policies aimed at democratizing access to production assets (capital, technology, training and land) are thus critical for both growth and equity. Rural development policies, as well as those aimed at increasing formalization of microenterprises, fall within this realm. This should be accompanied by a gradual extension of social security schemes to workers in small firms and to the self-employed.

The interaction between human capital and highquality employment and the effects of a better distribution of production assets are only two of the positive linkages between development and equity. There may also be favourable political economy linkages, as well as positive effects through the capital market and through the linkages among social cohesion, investment and productivity. Equity-development linkages were a favourite topic of development literature in the 1960s. Fortunately, they have now come back to the forefront of economic thinking (for a recent survey, see Aghion, Caroli and García-Peñalosa, 1999).

Given the crucial linkages between economic and social development, integrated policy frameworks should be designed. Such frameworks should explicitly take such linkages into consideration, as well as those existing among social policies (the supportive effects of different social policies, which may, in particular, be channelled through integrated poverty eradication programmes) and among economic policies (macromeso connections, particularly to facilitate the development of dynamic small business sectors). One of the weakest links, in this regard, is the lack of appropriate institutions for integrated policy frameworks. Such institutions should provide for the active participation of social actors and give a strong voice to the poor, should be equipped with effective systems for coordination between economic and social authorities in which social priorities are "mainstreamed" into economic policy, and should be guided by rules that facilitate the "visibility" of the 
social effects of economic policies. These rules should provide for the consideration of such effects by macroeconomic authorities (including central banks) on a regular basis, require budget proposals to include

\section{VI}

\section{Broader goals}

One of the most positive events of the past decade has been the full realization that development comprises broader goals (Stiglitz, 1998). The concept of "human development" or the even more recent concept of "development as freedom" (Sen, 1999) give expression to this perspective, but it is clearly a long-standing and deeply-rooted part of development thinking. Its most important manifestation is the gradual spread of global ideas and values, such as those of human rights, social development, gender equity, respect for ethnic and cultural diversity, and environmental protection. Nothing embodies this "globalization of values" more than the series of declarations issued by United Nations summits during the 1990s, including the Millennium Declaration. These global values, and particularly human rights in their dual dimension (civil and political rights, on the one hand, and economic, social and cultural rights, on the other), should be regarded as constituting the ethical framework for the design of development policy today.

The implications of this perspective run more deeply than current economic thought is willing to recognize. The central implication, drawing on Polanyi's work (1957), is that the economic system must be subordinated to broader social objectives. An emerging issue in this regard is the need to confront the strong centrifugal forces that characterize private affairs today. Indeed, in many parts of the developing (and industrialized) world, people are losing their sense of belonging to society, their identification with analyses of distributive effects, stipulate that these analyses be taken into account by Congress when a budget proposal is being considered, provide for similar practices in the case of proposals for tax reforms, etc. collective goals and their awareness of the need to develop ties of solidarity. This fact drives home how important it is to foster those bonds in order to "create society" and to arrive at a more widespread awareness of the social responsibilities of individuals and groups. Either the State or civil society can take the initiative. In this sense, as indicated in the introduction to this paper, "public affairs" should be viewed as the sphere in which collective interests come together, rather than as a synonym for State actions. It means, in other words, that all sectors of society need to participate more actively in democratic political institutions and that a wide range of mechanisms need to be developed within civil society itself to strengthen relationships of social solidarity and responsibility and, above all, to consolidate a culture of collective development founded upon tolerance of differences and a willingness to compromise.

The enormous intellectual challenges and practical tasks that are involved in the recognition of these factors should foster a sense of humility. The idea that "we already know what must be done" is nothing more than a sign of arrogance on the part of the economics profession, which has only worsened since the rise to dominance of orthodox development thinking in the 1980s. Consideration of the unsatisfactory results of reforms and of the existing level of social discontent should -and is- leading many experts to rethink the development agenda. This is most welcome, but it is at best an incomplete, ongoing process.

\section{Bibliography}

Aghion, P., E. Caroli and C. García-Peñalosa (1999): Inequality and economic growth: The perspective of the new growth theories, Journal of Economic Literature, vol. 37, No. 1, Nashville, Tennesse, American Economic Association, December.

Amsden, A. (2001): The Rise of "The Rest": Challenges to the West from Late Industrializing Countries, New York, Oxford University Press.
Cornia, G.A. (1999): Liberalization, Globalization and Income Distribution, Working papers, No. 157, Helsinki, United Nations University (UNU)/World Institute for Development Economic Research (WIDER), March.

Eatwell, J. and L. Taylor (2000): Global Finance at Risk: The Case for International Regulation, New York, The New Press.

ECLAC (Economic Commission for Latin America and the 
Caribbean) (1951): Theoretical and Practical Problems of Economic Growth, Mexico City.

(1990): Changing Production Patterns with Social Equity.

The Prime Task of Latin American and Caribbean Development in the 1990s, LC/G.1601-P, Santiago, Chile.

(2000): Equity, Development and Citizenship, LC/G.2071/ Rev.1-P, Santiago, Chile.

Ffrench-Davis, R. (1999): Macroeconomía, comercio y finanzas para reformar las reformas en América Latina, Santiago, Chile, McGraw-Hill Interamericana.

Helleiner, G.K. (2000): Markets, politics and globalization: Can the global economy be civilized?, The Tenth Raúl Prebisch Lecture, Geneva, UNCTAD, 11 December.

Hirschman, A.O. (1961): La estrategia del desarrollo económico, Mexico City, Fondo de Cultura Económica (FCE).

Katz, J. (1976): Importación de tecnología, aprendizaje e industrialización dependiente, Mexico City, FCE.

Kaul, I., I. Grunberg and M.A. Stern (comps.) (1999): Global Public Goods. International Cooperation in the 21st Century, New York, United Nations Development Programme (UNDP)/ Oxford University Press.

Ocampo, J.A. (2000): Developing Countries'Anti-Cyclical Policies in a Globalized World, Temas de coyuntura, No. 13, Santiago, Chile, ECLAC, October.

(2001): Recasting the international financial agenda, in J. Eatwell and L. Taylor (comps.), External Liberalization, Economic Performance, and Social Policy, New York, Oxford University Press, in the press.

Ocampo, J.A. and L. Taylor (1998): Trade liberalisation in developing economies: Modest benefits but problems with productivity growth, macro prices, and income distribution, The Economic Journal, vol. 108, No. 450, Oxford, U.K., Basil Blackwell, September.

Polanyi, K. (1957): The Great Transformation: the Political and Economic Origins of Our Time, Boston, Beacon Press.

Rodrik, D. (1997): Has Globalization Gone Too Far?, Washington, D.C., Institute for International Economics (IIE).
(1999): The New Global Economy and the Developing Countries: Making Openness Work, Policy Essay, No. 24, Washington, D.C., Overseas Development Council (ODC).

Ros, J. (2000): Development Theory and The Economics of Growth, Ann Arbor, The University of Michigan Press, September.

Rosenstein-Rodan, P.N. (1943): Problems of industrialization of Eastern and South-Eastern Europe, The Economic Journal, vol. 53, Oxford, U.K., Basil Blackwell, June-September.

Schumpeter, J. (1961): The Theory of Economic Development, Oxford, U.K., Oxford University Press.

(1962): Capitalism, Socialism and Democracy, third edition, New York, Harper Torchbooks.

Sen, A. (1999): Development as Freedom, New York, Alfred A. Knopf.

Stiglitz, J.A. (1998): More Instruments and Broader Goals: Moving Toward the Post-Washington Consensus, WIDER annual lectures, No. 2, Helsinki, UNU, wIDER, January.

Sunkel, O. (ed.) (1993): Development from Within. Toward a Neostructuralist Approach for Latin America, Boulder, Colorado, Lynne Rienner Publishers.

Taylor, L. (1991): Income Distribution, Inflation and Growth, Cambridge, Massachusetts, The MIT Press.

UNCTAD (United Nations Conference on Trade and Development) (1999): Trade and Development Report 1999, Geneva.

UNDP (United Nations Development Programme) (1999): Human Development Report 1999, New York.

United Nations (2000): United Nations Millennium Declaration, New York, Millennium Summit 2000, 6-8 December.

Williamson, J. (1997): The Washington Consensus revisited, in L. Emmerij (comp.), Economic and Social Development into the XXI Century, Washington, D.C., Inter-American Development Bank (IDB)/The Johns Hopkins University Press.

World Bank (2001): World Development Report 2000/2001. Attacking Poverty, Washington, D.C. 